\title{
MEMOIR
}

\section{FRANCIS HERBERT SPRATLING}

Frank Spratlung died suddenly on 16 January 1977 aged 69, while still enjoying an active retirement. He was one of the many eninent Old Blues who have adorned the actuarial profession. After 8 years at Christ's Hospital, he joined the Liverpool London and Globe Insurance Company on leaving school in 1925 . In 1930 he became principal assistant in the Actuarial Department of the Royal London Mutual Insurance Society.

Spratling became a Fellow of the Institute in 1932 and thereafter he gave virtually continuous service to the Institute and the profession for over 40 years. He was a member of the Committee of the Students' Society from 1936 to 1943 and in 1937 became Joint Fditor of the Students' Society Journal, the same year in which he became a tutor. He was appointed an examiner in 1940. He served on Council for two terms between 1949 and 1963 and during this period he was successively Chairman of the Students' Society, Chairman of the Appointments Board, Vice-President and Chairman of the Professional Guidance Committee. He continued in the latter position for four years after retiring from Council, while undertaking the arduous task of drafting, and securing acceptance of, the Institute's Memorandum on Professional Guidance and Practice, the original 'green booklet'. At the time of his death he was still a member of two Institute committees on both of which his wise counsel, based on long experience and independent judgment, was highly valued.

Soon after obtaining his Fellowship, Spratling joined London Transport as Menzler's assistant. He quickly became involved in duties ranging far more widely than those usually expected of an actuary at that time, since Menzler was both adviser and speech-writer to the Chairman, Iord Ashfield, and forecaster and planner for the Vice-Chairman, Frank Pick. Spratling was in fact seconded to Pick's personal office in 1939. Thereafter he held a wide range of successively more senior posts culminating in a period of 17 years as Chief Establishment Officer. After his official retirement in 1972 he continued to work for London Transport, as a consultant, until his death.

It was perhaps not surprising that an assistant of Menzler's should be someone who would add lustre to the profession's record and image in the 'wider field'. But Spratling achieved this with his own style and in his own way, and continued to do so throughout his career. It is clear that his success was firmly based on work done in the traditional field. His first main task at London Transport had been to amalgamate up to 100 pension and other staff benefit funds belonging to the many different railway, bus and tramway undertakings which had been brought together by the London Passenger Transport Act, 1933. He once said that it was hard to decide the relative values of an expectation of $10 \mathrm{~s}$. a week from a solvent fund and that of $£ 5$ a weck from an insolvent one, but that was easier than to persuade the fund members that he had got the answer right. With his actuarial training on the one hand, however, and his temperament on the other, he was able to solve both parts of the problem with great success. In a similar way he showed, in the wider field also, a tremendous power to analyse a problem so as to find the best solution, and then to convince others that it was the best solution by quiet, carefully reasoned persuasion. He was highly respected for this by all his colleagues, professional and lay alike.

These powers meant that Spratling's services were in great demand in other activities. For example, he served twice as a member of the Road Transport Industry Training Board where he did sterling work on that Hoard's thorny problems, in the fields of levies and grants, with its huge, diverse and generally complaining industry.

The profession's expansion into the wider field is of course intended to be beneficial to both, and often leads to a two-way fiow of ideas. Spratling's work at London Transport in developing the Central Record of Staff Statistics was the subject of a joint paper with F. J. Lloyd which 
was submitted to the Institute in February 1951. He was also the joint author, with Dr Leslie Norman, of Health in Industry which was in the Institute's Course of Reading for many years. Away from the office, in spite of his fondness for gardening and photography and his interest in many of the arts, especially music, Spratling gave his time unsparingly to a wide range of church activities and charitable organizations. It is not easy to write of these because his good works were done by stealth. In his twenties, however, he became involved in Toc $\mathbf{H}$ and lived, as warden, in Pierhead House, that organization's hostel in Wapping where he also ran a boys' club. Later he served for a long period as people's warden at St Mary's, Osterley. After moving to Guildford, a few years before he retired, he attended the church of St John the Evangelist, Merrow and became rector's warden. In the problems of both parishes his abilities and wisdon were made freely available and were highly appreciated. In retirement he also gave much time, as Honorary Treasurer, to a local mother-and-baby home. Throughout his life he was quiet, conscientious and concerned; these qualities stemmed from a Christian faith which was both firm and deep.

He was devoted to his family and enjoyed two suprenely happy marriages, the first with Vera who died in 1973 and the second, all too short, with Nancy. He also left a son, and three grandchildren. The sympathies of all Frank's friends are with his family in their bereavenent.

c. J, CORNWALL 